\title{
Hogyan tovább? \\ Adalékok a regionális tudomány hazai jövőképéhez
}

\author{
Quo vadis? \\ Contributions to the domestic vision of regional science \\ KOCZISZKY GYÖRGY
}

\begin{abstract}
KOCZISZKY György: egyetemi tanár, Miskolci Egyetem Világ- és Regionális Gazdaságtan Intézet; 3515 Miskolc- Egyetemváros; regkagye@uni-miskolc.hu; https://orcid.org/ 0000-0002-7032-7266
\end{abstract}

KULCSSZAVAK: regionális tudomány; oktatás; mester- és PhD program

\begin{abstract}
György KOCZISZKY: professor, University of Miskolc, Institute of World and Regional Economics Education, Master and PhD Program; Egyetemváros, H-3515 Miskolc, Hungary; regkagye@uni-miskolc.hu; https://orcid.org/0000-0002-7032-7266
\end{abstract}

KEYWORDS: regional sciences; education; Master and PhD program

Adott tudományterület helyzetét, társadalmi elfogadottságát, megítélését, belső (pl. művelőinek felkészültsége, tudományos eredményeik ismertsége és elismertsége, szűkebb és tágabb közösségek fejlődésére gyakorolt hatása) és külső tényezők (pl. gazdaság- és társadalompolitikai fogadtatása) együttmozgása határozza meg.

Kegyelmi időszakban a tudományterület művelőinek eredményei pozitívan befolyásolják a társadalmi, gazdasági folyamatokat, a gazdaságpolitikai döntések irányát. Amennyiben az eredmények, illetve azok hasznosulása nem számottevő vagy következtetéseire nincs fogadókészség, annak többnyire személyi és tárgyi következményei vannak.

Indokolt tehát, hogy időszakonként áttekintsük egy-egy diszciplína helyzetét, tudományos eredményeit, társadalmi fogadtatását, választ keressünk a „hogyan tovább" kérdésére politikai indulatoktól, anyagi és egzisztenciális érdekektől mentesen. Köszönet illeti azokat, akik erre vállalkoznak!

Ennek hiánya, a „radarok” kikapcsolása, vagy jelzéseik figyelmen kívül hagyása szükségszerüen negatív következményekkel jár. Jól példázza ezt az 1970-es években indult, majd iskolává terebélyesedett, az 1990-es évekre már mainstream monetáris közgazdaságtan, mert összhangban volt a globális jelentőségű pénzügyi központok mértékadó szervezeteinek, valamint a monetáris politikát formálók érdekeivel. Zárt logikai keretrendszere, ökonometriai és empirikus alátámasztottsága pedig rangot adott művelőinek. Az „elit közgazdaságtan” önteltsége, 
tévedhetetlenségbe vetett hite is hozzájárult ahhoz, hogy a 2008-as pénzügyi válság művelőit és alkalmazóit egyaránt felkészületlenül érte.

A fentieket előrebocsátva természetesnek és indokoltnak tartom a regionális tudomány látleletének összeállítását, a „hogyan tovább” kérdésére vonatkozó válaszok keresését. Különösen indokolt ez annak ismeretében, hogy tudományterületünk esetében is két hatás érvényesül. Egyrészt az elmúlt három évtizedben megerősödött a közgazdasági gondolkodásban is a térszemlélet, de nem eresztett olyan erős gyökereket, hogy bekerüljön a közgazdasági gondolkodás fősodrába. Másrészt a 2008-as pénzügyi válság hatására a közgazdaságtan, illetve a gazdaságpolitika mértékadó művelői a válság utáni helyzet kezelésére koncentrálták és koncentrálják ma is erőiket, így a térgazdaságtani, illetve regionális tudományi összefüggések háttérbe szorultak, illetve új megközelítést kaptak (pl. új következtetés, hogy a szegényebb régiók kitettsége jóval kisebb volt, mint a centrumtérségeké). A tértudományok eredményei iránt tapasztalható érdeklődés csökkenésének tehát tudományos, oktatási, gazdaságpolitikai oka is lehet.

A Lengyel Imre, Nemes Nagy József, Rechnitzer János és Varga Attila által jegyzett vitairat két témakör - „, helyünk a hazai és nemzetközi tudományos kapcsolatrendszerben” és „a főbb kutatási tématerületek néhány jellemzője”- köré csoportosította főbb megállapításait. Ehhez kapcsolódva és a terjedelmi korlátokhoz igazodva, három pontban foglalom össze gondolataimat.

(1) Az elméleti kérdések újragondolása. Aligha vitatható: a makrogazdaságtan művelői új kihívások előtt állnak, amelyek alapvető kérdése, hogy a neoklasszikus közgazdaságtant leváltó új közösségi gazdaságtan milyen új paradigmákra építkezzen (lásd a London School of Economics tanárainak és diákjainak elhíresült 33 pontját, amelyben a közgazdaságtan neoklasszikus megközelítését, illetve kritika nélküli oktatását bírálják). Evvel összhangban az is megfontolás tárgya, hogy a regionális közgazdaságtan neoklasszikus, többségében lineáris, a Rostow-i „határtalan" növekedés szemléletű modelljei helyett milyen fenntartható közösségi fejlődési modellekre van szükség. Ennek során érdemes újragondolni többek között az általános és térbeli egyensúlyelmélettel kapcsolatos ismereteket, válaszokat kell keresni a fiskális és a monetáris lazítás területi gazdasági fejlődésre, inflációra, beruházási és megtakarítási hajlandóságra gyakorolt hatásaira.

(2) Horizontális szemléletü ismeretátadás. A regionalista képzés a bolognai rendszerű közgazdászképzésnek nyertese, de vesztese is egyben. A szakok közötti verseny már az alapszakra való jelentkezésnél indul, majd a hallgatók döntő többsége az adott szak mesterkurzusán folytatja tanulmányait. Regionális alapszak hiányában ez eleve hátrányt jelentett, ami csak úgy oldható fel, ha már az alapszakos hallgatók kötelező tárgyai között szerepel a „térgazdaságtan” című tárgy. Ehhez a szakok, illetve a szakvezetők közötti (jelenleginél jobb) együttműködésre van szükség.

Jelentősen visszaesett a másoddiplomát adó képzéseink iránti igény is, amelynek egyértelműen munkaerőpiaci okai vannak (a végzettek elhelyezkedési 
lehetőségei többek között a regionális ügynökségek „de facto” felszámolásával megszűntek). Holott a tértudományi szemlélet iránti igény változatlan, amit jelez, hogy a doktori képzésben egyre többen készítenek regionális gazdaságtan tématerülethez kapcsolódó disszertációt. Ezt igazolja többek között, hogy a Miskolci Egyetem Gazdaságtudományi Kara Doktori Iskolája keretében regionális tudományi alprogram indult.

(3) Gazdaságpolitikai szerepvállalás. A területi politika centralizációjával egyidejűleg érezhetően csökkent a szakmai vélemények iránti igény a szakpolitikai kérdésekben. Érdemes lenne megfontolni a Magyar Regionális Tudományi Társaság átalakítását kamarává. Az utóbbi szervezeti, jogi formának a nemzetközi gyakorlat szerint is nagyobb a véleményformáló, érdekképviseleti súlya, közhatalmi jogosítványokat szerezhet magának, azaz lehetősége van arra, hogy az állam egyes közfeladatok ellátását delegálja számára (ennek megfelelően jogállását törvény határozza meg).

Összefoglalóan elmondható, hogy a tértudományok elfogadottságáért, eredményeiért a téma iránt elkötelezett korábbi generációk megdolgoztak, sokat tettek. A helyükre lépő generációk akkor járnak el helyesen, ha ismerik az ide vezető utakat, illetve a buktatókat, de a jövőben nem a hagyományos úton akarnak haladni, hanem az elődök szorgalmával és kitartásával keresik az innovatív megoldásokat, kapcsolatokat és összefüggéseket. 